\title{
Kelola
}

\section{Teori dan Implementasi Gaya Kepemimpinan Kepala Sekolah}

\author{
Nasib Tua Lumban Gaol \\ Insitute of Education, National Taiwan Ocean University \\ Universitas Pelita Harapan Medan \\ nasib.tlg@gmail.com
}

\begin{abstract}
Indonesia faces many problems in education. The main problem is raised from the low ability of the headmaster to manage the school. This is related to leadership style. This study aims to explore leadership styles in the field of education and discusses how headmasters should apply leadership styles in schools. Some appropriate leadership styles are applied by the headmaster consisting of (1) managerial leadership, (2) transformational leadership, (3) transactional leadership, (4) instructional leadership and (5) positive leadership. Therefore, the headmaster not only applies a leadership style while managing the school but must be able to combine and contextualize leadership styles based on the need to obtain school goals.
\end{abstract}

Keywords: education management, headmaster, leadership style

\section{Article Info}




\section{PENDAHULUAN}

Kualitas pendidikan sangat ditentukan oleh keberhasilan proses pembelajaran di lembaga pendidikan. Sekolah sebagai lembaga pendidikan membutuhkan kepala sekolah yang mampu memimpin dan mengelola sekolah dengan profesional. Wiyono (2017) menyatakan bahwa kepemimpinan kepala sekolah merupakan salah satu aspek yang menentukan keberhasilan pendidikan di sekolah. Hal tersebut dikarenakan kepala sekolah memiliki peran penting untuk melakukan peningkatan dan pengembangan sekolah secara berkelanjutan (Yang, 2014).

Kepala sekolah membutuhkan kompetensi yang memadai. Ini bertujuan supaya setiap permasalahan dan pengembangan sekolah dapat dilakukan oleh kepala sekolah. Adapun kompetensi yang dibutuhkan oleh kepala sekolah adalah

(1) kompetensi personal, (2) manajerial, (3) supervisi, (4) interpreneurship, dan (5) sosial (Wiyono, 2017). Selain itu, berdasarkan hasil penelitian Ross dan Cozzens (2016), ditemukan kompetensi utama yang harus dimiliki oleh kepala sekolah, yaitu: (1) Assessment, (2) Instructional Leadership, (3) Unity of Purpose, (4) Visionary Leadership, (5) Diversity, (6) Learning Community, (7) Reflection, (8) Organizational Management, (8) Professional Development, (9) Collaboration, (10) Curriculum and Instruction, (11) Professionalism.

Namun, pada kenyataannya, terdapat permasalahan mendasar yaitu masih banyak kepala sekolah di Indonesia yang tidak mengetahui bagaimana menggunakan wewenang yang dimiliki untuk mengelola sekolah yang dipimpin karena takut membuat perubahan (Sofo, Fitzgerald \& Jawas, 2012). Hal ini menunjukkan bahwa kemampuan kepala sekolah di Indonesia masih lemah dalam mengelola sekolah.

Silfianti (2013) menemukan beberapa fenomena kritis terhadap kondisi sekolah yang dikaitkan dengan ketidakmampuan kepala sekolah mewujudkan sekolah yang efektif di Indonesia. Pertama, kepala sekolah masih kurang mampu dalam memelihara fasilitas sekolah. Fasilitas belajar tidak terkelola dengan baik sehingga mengakibatkan suasana belajar di lingkungan sekolah tidak begitu efektif.
Misalnya adalah kondisi kursi, meja, dan lemari sekolah yang sudah rusak. Kondisi yang demikian ini membuat siswa tidak nyaman untuk belajar.

Kedua, kepala sekolah tidak mampu menciptakan budaya dan suasana sekolah yang kondusif. Hubungan di antara sesama guru dan staf kependidikan lainnya sering sekali tidak baik. Akibatnya, lingkungan kerja di sekolah menjadi tidak baik karena ada beberapa guru memiliki konflik interpersonal dengan guru atau staf kependidikan lainnya.

Ketiga, kepala sekolah juga kurang mampu melibatkan para personil sekolah supaya aktif dalam berbagai kegiatan di sekolah. Lemahnya kemampuan kepala sekolah dalam melibatkan para personil sekolah baik guru maupun tenaga kependidikan menjadi permasalahan mendasar di sekolah. Artinya, baik guru maupun tenaga kependidikan tidak dapat memaksimalkan kontribusinya dalam mewujudkan pengembangan sekolah karena kepala sekolah tidak berkompeten untuk memberdayakan sumberdaya manusia yang ada di sekolah.

Keempat, kepala sekolah juga tidak mampu mengarahkan para guru supaya menyusun dan mengembangkan silabus dan RPP (Rencana Pelaksanaan Pembelajaran). Kecenderungan guru adalah menggunakan RPP dari sekolah lain atau hanya menggunakan RPP dari situs internet. Dalam kasus ini sebenarnya, peran kepala sekolah sebagai pemimpin pengajaran telah gagal.

Kelima, kepala sekolah cenderung tidak melibatkan para guru dalam komite sekolah untuk pengambilan keputusan. Kepala sekolah selalu mendominasi dalam setiap pengambilan keputusan. Kemampuan kepala sekolah secara sosial maupun kooperatif adalah penyebab utamanya.

Selanjutnya, Sofo, Fitzgerald dan Jawas (2012) menyatakan bahwa permasalahan kepemimpinan pendidikan dan reformasi sekolah yang ada di Indonesia sangatlah penting, akan tetapi kedua topik tersebut masih terabaikan pada kajian literatur yang dipublikasikan. Dengan demikian, karena lemahnya kemampuan kepala sekolah dalam mengelola sekolah dan minimnya kajian literature tentang kepemimpinan pendidikan terkhusus kepala sekolah di Indonesia, maka 
dianggap penting untuk melakukan kajian secara teoritis dan menemukan hal penting untuk diimplementasikan oleh kepala sekolah dari berbagai gaya kepemimpinan.

Oleh karena itu, yang menjadi rumusan permasalahan dalam tulisan ini adalah: (1) Apakah teori-teori gaya kepemimpinan yang relevan untuk diimplementasikan di sekolah yang ada di Indonesia? (2) Bagaimanakah implementasi gaya kepemimpinan dapat dilakukan oleh kepala sekolah?

Tulisan ini memberikan kontribusi signifikan baik secara teoritis maupun praktis. Secara teoritis, menambah temuan baru tentang gaya kepemimpinan pendidikan yang relevan untuk diimplementasikan di Indonesia. Secara praktis, memberikan pemahaman baru kepada kepala sekolah dan para stakeholder dalam mengelola lembaga pendidikan sekolah sehingga diharapkan akan terwujud sekolah yang efektif di Indonesia.

\section{PEMBAHASAN}

Kepemimpinan adalah sangat kompleks dan memiliki berbagai konsep. Northouse (2013) memfokuskan konsep kepemimpinan hanya pada empat komponen penting, yaitu (1) pengaruh, (2) proses, (3) komunitas, dan (4) tujuan bersama.

Tetapi, Abbas (2014) menyatakan bahwa kepemimpinan adalah kemampuan untuk menggerakkan segala sumber daya yang ada pada organisasi, sehingga dapat didayagunakan secara maksimal, guna mencapai tujuan yang telah ditetapkan. Meskipun ada perbedaan tentang konsep kepemimpinan, tetapi teori kepemimpinan tetap saja memberikan kontribusi penting dalam berbagai bidang, termasuk pendidikan.

Kepemimpinan dalam pendidikan menjadi sangat penting karena kepemimpinan kepala sekolah memiliki pengaruh signifikan terhadap kualitas pendidikan. Beberapa hasil studi terbaru telah menunjukkan bahwa ada hubungan yang signifikan antara kemampuan kepemimpinan kepala sekolah dengan efektifitas sekolah (Bolanle, 2013; Moorosi \& Bantwini \&, 2016; Boonla \& Treputtharat, 2014).

Sebenarnya, dengan adanya kemampuan yang memadai dan gaya kepemimpinan yang sesuai, kepala sekolah pasti mampu mewujudkan sekolah yang efektif. Namun karena kendala dalam memahami dan mengimplementasikan gaya-gaya kepemimpinan pendidikan di sekolah, sekolah tidak begitu berhasil sebagai wadah pendidikan.

Dengan demikian, ada beberapa gaya kepemimpinan yang dapat diimplementasikan oleh kepala sekolah di Indonesia ketika mengelola sekolah supaya efektif dan mencapai tujuan pendidikan, yaitu kepemimpinan manajerial, kepemimpinan transformasional, kepemimpinan transaksional, Pengajaran (Bush, 2008; 2015), dan positif (Chen, Tsai, Chen \& Wu, 2016).

\section{Gaya Kepemimpinan Manajerial}

Kepemimpinan manajerial lebih memfokuskan pada setiap hal supaya dapat terkelola dengan baik. Bush (2015) menyatakan "managerial leadership assumes that the focus of leadership ought to be on functions, task, and behaviors and if these functions are carried out completely, the work of others in the organization will be facilitated. Oleh karena itu, setiap bagian pada organisasi sekolah harus diposisikan dengan benar supaya tujuan sekolah dapat tercapai. Namun, kelemahan pada kepemimpinan manajerial ini adalah tidakmengikutsertakan konsep visi (Bush, 2008). Artinya, kepemimpinan manajerial lebih memfokuskan diri pada pengelolaan berbagai kegiatan supaya berhasil. Sehingga kepala sekolah dengan gaya kepemimpinan manajerial memiliki kecenderungan untuk mengurusi kegiatan-kegiatan sekolah, misalnya kegiatan lomba, perayaan event tertentu, dan lain sebagainya.

Meskipun demikian, gaya kepemimpinan manajerial sebenarnya memberikan dampak positif terhadap sekolah. Karena dengan kemampuan mengorganisir program yang dimiliki oleh kepala sekolah akan membawa suasana educatif dan tidak membosankan bagi guru dan peserta didik yang berada di lingkungan sekolah.

Selain membuat program sekolah terlaksana dengan baik, kepemimpinan manajerial juga dapat memberikan dampak postif terhadap guru-guru di sekolah. Penelitian menunjukkan bahwa gaya kepemimpinan manajerial berpengaruh terhadap kepuasan 
guru. Misalnya, Silfianti (2013) menemukan bahwa kompetensi manajerial yang dimiliki oleh kepala sekolah berkontribusi positif terhadap motivasi kerja guru. Ketika motivasi kerja guru semakin baik, maka guru akan memiliki kinerja lebih baik lagi dalam mendidik dan menjalin hubungan sosial degan guru dan staf kependidikan lainnya. Dengan adanya kontribusi positif dari gaya kepemimpinan manajerial kepala sekolah terhadap motivasi kinerja guru, tentu membawa dampak positif juga dalam mewujudkan peningkatan efektifitas sekolah karena guru memiliki semangat dan loyalitas terhadap sekolah.

\section{Gaya Kepemimpinan Transformasional}

Kepemimpinan transformasional adalah komprehensif karena memiliki pendekatan normatif terhadap kepemimpinan sekolah. Fokus utama kepemimpinan transformasional adalah pemimpin menemukan aktifitas yang memiliki pengaruh dan hasil (Bush, 2008; 2015). Northouse (2013) menyatakan ada lima faktor penting yang berkaitan dengan kepemimpinan transformasional, yaitu: (1) pengaruh ideal, (2) karisma, (3) motivasi yang menginspirasi, (4) rangasangan intelektual, dan (5) pertimbangan yang diadaptasi. Dengan adanya faktor-faktor ini kepala sekolah didorong supaya lebih bijak dalam bertindak dan berhadapan dengan para guru dan staf kependidikan di lingkungan sekolah.

Oleh karena itu, pemimpin transformasional adalah pemimpin yang cendurung mengadopsi pendekatan demokratis pada gaya kepemimpinannya (Giltinane, 2013). Sebagai hasilnya, ketika kepala sekolah mengimplementasikan gaya kepemimpinan transformasional dengan baik, maka akan memiliki potensi untuk melibatkan para steakholder dalam mencapai tujuan-tujuan pendidikan (Bush, 2015). Misalnya, ketika kepala sekolah memiliki kepemimpinan transformasional yang baik, maka kepala sekolah mampu melibatkan para guru, staf kependidikan, dan orang tua siswa sehingga berperan aktif untuk pengembangan efektivitas sekolah. Dalam konteks Indonesia, gaya kepemimpinan ini sangat dibutuhkan karena dengan adanya prinsip demokratis dalam pengelolaan sekolah akan mendorong semakin munculnya ide-ide kreatif dan inovasi untuk memajukan sekolah dari berbagai pihak.

$$
\text { Lebih lanjut, kepemimpinan }
$$

transformasional yang efektif membutuhkan kepercayaan antara pemimpin dan bawahan (Giltinane, 2013). Kepala sekolah yang memiliki gaya kepemimpinan transformasional berperan dalam mendorong pengembangan sekolah (Yang, 2014). Dengan demikian, kepala sekolah harus mampu membangun kepercayaan terhadap guru dan staf kependidikan sehingga guru dan staf kependidikan juga mampu mengembangkan kepemimpinan dan tanggung jawabnya. Selain itu, kepala sekolah juga harus membagikan visi dan misi sekolah kepada warga sekolah sehingga ini akan mewujudkan suasana kondusif untuk pembelajaran.

\section{Gaya Kepemimpinan Transaksional}

Gaya kepemimpinan transaksional adalah berorientasi pada tugas dan bisa efektif ketika berhadapan dengan deadline (Giltinane, 2013). Northouse (2013) menyatakan bahwa kepemimpinan transaksional berbeda dengan kepemimpinan transformasional. Hal tersebut dikarenakan pemimpin yang mengimplementasikan gaya kepemimpinan transaksional tidak menyesuaikan kebutuhan pengikut, tetapi berfokus pada pengembangan pribadi para anggota.

Pada umumnya, ada tiga tipe kepemimpinan transaksional, yaitu: Continget reward (Pemberian penghargaan saat target tercapai), management by exception active (ada intervensi sebelum terjadi permasalahan), dan managemen by exception-passive (ada intervensi ketika permasalahan muncul) (Giltinane, 2013). Ketiga tipe kepemimpinan ini sangat efektif untuk mencegah dan menyelesaikan permasalahan yang ada di lingkungan sekolah.

Oleh karena itu, di lingkungan sekolah, kepemimpinan transaksional dapat diimplementasikan dengan cara pemberian penghargaan kepada setiap yang telah memberikan kinerja terbaik dalam melaksanakan tugasnya. Selain itu, kepala sekolah juga dapat membantu guru yang terkendala dengan tugas mengajar atau permasalahan yang dihadapi dengan siswa atau dengan orang tua murid. Dan juga kepala 
sekolah dapat memberikan seminar atau pelatihan kepada para guru ketika guru tidak mampu dalam mengajar dengan metode yang kreatif. Pengimplementasian strategi ini akan semakin mendorong para guru semakin memiliki kinerja yang baik dan profesional dalam mengerjakan tugasnya.

\section{Gaya Kepemimpinan Pengajaran}

Gaya kepemimpinan pengajaran terdiri atas konsep khusus dan umum ( $\mathrm{Ng}, \mathrm{dkk}, 2015)$. Konsep khusus mendefinisikan kepemimpinan pengajaran sebagai tindakan yang secara langsung berkaitan dengan pengajaran dan proses belajar. Misalnya adalah kepala sekolah melakukan pengamatan langsung di dalam kelas. Sedangkan konsep kepemimpinan pengajaran umum mendefenisikan kepemimpinan pengajaran sebagai tindakan kepemimpinan yang secara tidak langsung mempengaruhi belajar siswa. Misalnya kepala sekolah menciptakan budaya dan penentuan waktu yang efektif di sekolah .

Hallinger dan Murphy (1985) merupakan ahli utama yang mengembangkan konsep kepemimpinan pengajaran. Hallinger dan Murphy mengajukan 10 aspek penting dalam kepemimpinan pengajaran, yaitu: (1) framing the school's goals, (2) communicating the school's goals, (3) coordinating the curriculum, (4) supervising and evaluating instruction, (5) monitoring student progress, (6) protecting instructional time, (7) providing incentives for teachers, (8) providing incentives for learning, (9) promoting professional development dan (10) maintaining high visibility.

Dari kesepuluh aspek kepemimpinan pengajaran tersebut, kepala sekolah harus mampu menjadi inisiator dan fasilitator dalam mengupayakan proses belajar mengajar di sekolah terlaksana dengan baik. Selain itu, kepala sekolah juga harus mampu menciptakan budaya organisasi di sekolah sekondusif mungkin sehingga prestasi belajar siswa dan kinerja guru dapat meningkat.

\section{Gaya Kepemimpinan Positif}

Gaya kepemimpinan positif adalah gaya kepemimpinan yang baru dikembangkan dari konsep positif. Chen, Tsai, Chen dan $\mathrm{Wu}$ (2016) menyatakan kepemimpinan positif adalah tipe pemimpin yang mengurusi berbagai hal dengan melibatkan pemikiran positif sehingga terwujud situasi yang memaafkan, simpatik, dan penuh kasih. Selain itu, tipe kepemimpinan ini mengupayakan adanya saling mendukung satu sama lain di antara anggota-angota supaya saling peduli dan mengasihi untuk menciptakan hubungan positif di tempat kerja.

Hasil penelitian Chen, dkk (2016) membuktikan bahwa kepemimpinan positif berhubungan signifikan dengan efektifitas sekolah yang dimediatori oleh budaya organisasi sekolah. Pentingnya seorang pemimpin yang berpikiran positif sangat mendukung dalam mewujudkan lingkungan sekolah yang kondusif. Artinya kepala sekolah harus melakukan yang benar dan memiliki optimis.

Penerapan gaya kepemimpinan positif dipandang penting dilakukan oleh kepala sekolah di Indonesia. Pada umumnya sekolah di Indonesia terdiri dari berbagai ras, suku, dan agama. Oleh karena itu, kepala sekolah harus mampu memiliki pola pikir positif supaya dapat mewujudkan suasana sekolah yang kondusif dan demokratis sehingga dapat terwujud sekolah yang efektif.

\section{SIMPULAN}

Kepemimpinan merupakan hal yang penting dalam dunia pendidikan. Kepemimpinan kepala sekolah sangat menentukan peningkatan dan pengembangan sekolah untuk selanjutnya. Tanpa adanya kemampuan yang memadai dalam mengimplementasikan gaya kepemimpinan, kepala sekolah akan menemukan berbagai kesulitan dalam mewujudkan sekolah yang efektif. Oleh karena itu, kepala sekolah harus mampu mengimplementasikan gaya kepemimpinan manajerial, transformasional, transaksional, pengajaran, dan positif supaya sekolah dapat menjadi wadah pembelajaran yang efektif.

Proses implementasi dari lima gaya kepemimpinan kepala sekolah (manajerial, transformasional, transaksional, pengajaran dan positif) dapat dilakukan dengan cara: (1) mengkonsep setiap program sekolah dengan efektif dan efisien, (2) memberikan pengaruh yang berdampak signifikan kepada setiap 
warga sekolah (guru, staf kependidikan, dan siswa) dan stekeholder, (3) mengembangkan profesionalisme guru maupun staf kependidikan, (4) menciptakan proses pembelajaran dan iklim organisasi sekolah yang kondusif, (5) memiliki persepsi positif dalam mengelola sekolah.

Untuk mengembangkan kemampuan kepala sekolah dalam mengimplementasikan gaya kepemimpinan, maka pemerintah dapat memberikan program pelatihan dan kepemimpinan kepada para kepala sekolah. Misalnya, pemerintah dapat bekerja sama dengan Perguruan Tinggi untuk merancang program pengembangan kepemimpinan kepala sekolah. Program ini akan membantu kepala sekolah dalam mengelola sekolah.

Kepala sekolah sebagai pengelola sekolah harus berusaha mengimplemen-tasikan berbagai gaya kepemimpinan dalam mengelola sekolah. Hal ini akan meningkatkan iklim dan kualitas sekolah menjadi lebih baik. Selain itu kepala sekolah juga dapat melakukan kunjungan ke beberapa sekolah untuk melakukan diskusi dengan kepala sekolah lain. Kunjungan sekolah tersebut bisa dilakukan di kota atau provinsi yang berbeda. Kegiatan ini dapat mendorong kepala sekolah supaya lebih aktif dalam pengembangan sekolah.

\section{DAFTAR PUSTAKA}

Abbas, S. (2014). Manajemen Perguruan Tinggi. Jakarta: Kencana.

Bolanle, A. O. (2013) Principals' Leadership Skills and School Effectiveness: The Case of South Western Nigeria. World Journal of Education. 3 (5), 26-33.

Moorosi, P. \& Bantwini, B. D. (2016). School District Leadership Styles and School Improvement: Evidence from Selected School Principals in the Eastern Cape Province. South African Journal of Education. 36(4), 1-9.

Boonla, D. \& Treputtharat, S. (2014). The Relationship between the Leadership Style and School Effectiveness in School under the office of Secondary Education. Procedia Social and Behavioral Sciences. 112 (2014), 991 $-996$.
Bush, T. (2008). Leadership and Management Development. London : SAGE Publication Ltd.

Bush, T. (2015). Organisation Theory in Education: How does in inform school leadership? Journal of Organizational Theory in education. 1 (1), 35-47.

Bush, T. \& Glover, D. (2014). School Leadership models: What we do know? School Leadership \& Management. 34 (5), 553-571.

Chen, C., Tsai S., Chen, H., \& Wu, H. (2016) .The Relationship between the Principal's Positive Leadership and School Effectiveness-Take School Organizational Culture as The Mediator. European Journal of Psychological Research. 3 (2), 12-23.

Giltinane, CL. (2013) . Leadership Style and Theories. Nurshing Standard. 27 (41), 35-39.

Hallinger, P., \& Murphy, J. (1985). Assessing the Instructional Leadership Behavior of Principals. Elementary School Journal. 86 (2), 217-248.

Ng, F.S.D., Nguyen, T. D., Wong, K.S.B., \& Choy, K. W. W. (2015). Instructional leadership practices in Singapore. School Leadership \& Management. 35 (4), 388-407.

Ross, D. J. \& Cozzens, J. A. (2016). The Principalship: Essential Core Competencies for Instructional Leadership and Its Impact on School Climate. Journal of Education and Training Studies. 4 (9), 162-176.

Sofo, F., Fitzgerald, R., \& Jawas, U. (2012). Instructional Leadership in Indonesian School reform: Overcoming the problems to move forwad. School Leadership and Management. 32 (5), 503-522.

Northouse, P. G. (2013). Kepemimpinan: Theori dan Praktik (Terjemahan), Jakarta: PT. Indeks.

Wiyono, B. B. (2017). The Effect of Selfevaluation on the Principals' Transformational Leadership, Teachers' Work Motivation, Teamwork Effectiveness, and School Improvement. International Journal of Leadership in Education, 1-21. 
Teori Dan Implementasi Gaya Kepemimpinan Kepala Sekolah | Nasib Tua Lumban Gaol

Silfianti. (2013). Kontribusi kompetensi manajerial kepala sekolah terhadap motivasi kerja guru SMP Negeri di Kecamatan Padang Timur. Jurnal Manajemen Administrasi Pendidikan. 1 (1), 220-461.

Yang, Y. (2014). Principal's Transformational Leadership in School Improvement. International Journal of Educational Management, 28 (3), 279-288. 